\title{
Import Intensity of Production, Tasks and Wages: Micro-Level Evidence for Poland
}

\author{
Aleksandra Parteka
}

\begin{abstract}
A B S T R A C T
Objective: This article relates to recent literature on labour market consequences of production fragmentation within Global Value Chains, analysed in the presence of workers' heterogeneity and differences in the task content of jobs. The main aim is to assess if there is a relationship between wages of Polish workers and the degree of Polish production dependence on imported inputs.

Research Design \& Methods: Using microdata from EU-SILC on workers from Poland observed in 2008-2014, we estimate a Mincerian model, augmented by a measure of task content of occupations and the industry level index of the import intensity of production computed with input-output data and accounting for good's production sequence). IV estimation is employed to account for potential endogeneity between the import intensity of production and wages.
\end{abstract}

Findings: Regression results suggest that negative relationship between wages of Polish workers and the dependence of their sector of employment on foreign inputs is magnified by the routinisation level of the occupation. Hence occupation-specific task requirements play a role.

Implications \& Recommendations: It implies that not all the Polish workers are affected in the same. The movements towards jobs with higher degree of non-routine content could protect against negative wage effects of fragmentation.

Contribution \& Value Added: The relationship between wages in Poland and the reliance on foreign inputs and GVCs links has not yet been studied from the micro-level task-based perspective. This article fills in this gap.

\begin{tabular}{ll}
\hline Article type: & research paper \\
& import intensity of production; global value chains; production frag- \\
& mentation; wages; tasks
\end{tabular}

JEL codes: J31, J24, F16, F66

\section{Suggested citation:}

Parteka, A. (2018). Import Intensity of Production, Tasks and Wages: Micro-Level Evidence for Poland. Entrepreneurial Business and Economics Review, 6(2), 71-89. https://doi.org/10.15678/EBER.2018.060204 


\section{INTRODUCTION}

One of the main topics in recent international economics literature involves the analysis of so-called 'trade in tasks' ${ }^{1}$ and its consequences for the labour market outcomes observed in the countries involved in the process of global production sharing. It reflects the increasing importance of production fragmentation across countries and the proliferation of global value chains (from now on: GVCs), widely documented in the literature using trade in value added data (among others: Costinot, Vogel, \& Wang, 2012; Johnson \& Noguera, 2012; Johnson \& Noguera, 2016; Koopman, Wang, \& Wei 2014; Los, Timmer \& Vries, 2015; Timmer, Erumban, Los, \& Stehrerand de Vries, 2014; Timmer, Los, \& Stehrerand de Vries, 2016).

Clearly, not all workers are affected in the same way. While initially the focus was on skilled-unskilled workers' division (Wood, 1995), recently more attention has been paid to a proper distinction of tasks which are performed by workers on the job (WTO, 2017). The prediction is that workers employed in occupations which are more intense in the routine (repetitive) tasks are more at risk of experiencing downward pressure on wages (or a job loss) due to the relocation of some of the activities abroad or due to technological replacement (Autor, 2013). ${ }^{2}$

In this article we relate to recent literature on the labour market consequences of crossborder production links in the presence of labour market agents' heterogeneity and differences in the task content of jobs. We focus on one of the main labour market outcomes: wages. In particular, we study the process of wage determination in Poland from a microlevel task-based perspective. The main aim of the article is to determine if there is a relationship between wages of Polish workers and the degree of the Polish production dependence on imported inputs. The hypothesis to be tested empirically is the following: negative relationship between wages of Polish workers and the dependence of their sector of employment on foreign inputs is magnified by the routinisation level of the occupation.

To this aim, in the empirical part of this study we merge the information on individual wages of Polish workers with the degree of the dependence of their sectors of employment on foreign production. The latter is measured with an indicator of global import intensity of production recently proposed by Timmer et al. (2016). We estimate the micro-level wage regression model in which the production dependence on imported inputs acts as an additional factor possibly influencing wages, once all the other dimensions of the wage determination process have been taken into account. We thus take into account different dimensions of the wage determination process: individual characteristics of workers and their job, regional or industry specificity, the task content of workers' occupations and the characteristics of the sectors in terms of involvement into global production.

\footnotetext{
${ }^{1}$ The term comes from the 'theory of the global production process that focuses on tradeable task' by Grossman and Rossi-Hansberg (2008). Since then numerous papers analysed, both empirically and theoretically, the phenomenon of trade in the presence of globally fragmented production and task specialisation, using either the names 'trade in tasks' or 'trading tasks' or 'task trade' (among others: Baldwin \& Robert-Nicoud, 2014; Becker \& Muendler, 2015; Grossman \& Rossi-Hansberg, 2012).

${ }^{2}$ Apart from trade-driven mechanisms, the technology has also a strong impact on labour markets. See recent WTO report (WTO, 2017, 76-99) for the discussion on the impact of technology on labour market outcomes.
} 
The analysis is based on the microdata coming from the EU-SILC (The European Union Statistics on Income and Living Conditions) and the analysed sample covers employees from Poland observed in 2008-2014. We acknowledge the fact that task requirements of occupations differ across countries (Marcolin, Miroudot, \& Squicciarini, 2016), so we rely on newly available country-specific routinisation indices, kindly provided to the author by OECD. By doing so we address the limits of the existing literature which ignores country specificity and relies on the occupational task profile typical for the U.S.

The structure of our article is as follows: in Section 2 we present the review of recent literature on the effects of production fragmentation on globally integrated labour markets. We focus on 'task approach' literature and a significant progress in the methodology of the task content measurement. In Section 3, we present our data and crucial descriptive statistics on wages across different task categories of occupations. The empirical model and the results of its estimation are presented in Section 4. Finally, Section 5 concludes.

\section{LITERATURE REVIEW}

The literature assessing the impact of global production links (production fragmentation, offshoring, etc.) on domestically employed workers has a long tradition. The fact that different stages of production can be performed in various locations has important consequences for the labour markets, mainly stemming from the relocation of some of the activities abroad and the resulting changes in domestic labour demand (Acemoglu \& Autor, 2011; Autor, Dorn, \& Hanson, 2015; Baugmarten, Geishecker, \& Görg, 2013; Becker, Ekholm, \& Muendler, 2013; Becker \& Muendler, 2015).

Early literature on the labour market consequences of trade (especially North-South intermediate goods trade) focused on the differences between skilled and unskilled workers and the potential threat that trade with less developed (typically low wage) countries can create for less skilled workers. The issue of the rising wage inequality between skilled and unskilled workers due to trade and production fragmentation was analysed, among others, by Wood (1995) or Feenstra and Hanson (2001). However, according to the 'trade in tasks' theory (Grossman \& Rossi-Hansberg, 2008), the relocation of activities which are easier to be coordinated even at a large distance (routine tasks) can endanger domestic workers involved in less demanding stages of production (typically manual, routine) and favour workers performing non-routine tasks. More recently, the empirical focus has moved towards the approach accounting for the specificity of tasks performed in different occupations which in turn affects the degree of their offshorability (among others: Acemoglu \& Autor, 2011; Autor, 2013; Autor \& Handel, 2013; Autor \& Price, 2013; Baumgarten, Geishecker, \& Görg, 2013; Becker et al., 2013; Becker \& Muendler, 2015; Fortin \& Lemieux, 2016; Hardy, Keister, \& Lewandowski, 2016a, 2016b, 2018).

In the literature (Baumgarten et al., 2013; Becker et al., 2013; Becker \& Muendler, 2015 ) it is now widely accepted that the conventional classification of workers into skilled and unskilled (typically on the base of the information on their education) is not necessarily linked to the type of tasks workers perform on the job (e.g. a person with tertiary education can be employed in a highly routine job). Consequently, the initial focus on skilled-unskilled workers' division has recently moved towards deeper analysis. Given the split of the production value chain into specific tasks, the analysis of changes observed on the labour markets has emphasised the differences across occupations and the type of 
tasks they require (so called 'task content of jobs'). As underlined in one of the first studies on this issue (Autor, Levy, \& Murnane, 2003), tasks differ from skills ('A skill is a worker's stock of capabilities for performing various tasks'). Hence, skills can be perceived as workers' ability to perform specific tasks. The development of the 'task approach' literature (see Autor, 2013 for an overview) reflects also significant progress in the methodology of the task content measurement, which we present below.

The 'task content of jobs' was studied primarily with respect to the American labour market. In their seminal paper, Autor et al. (2003) analysed the task content of jobs in the U.S. in the context of the routine-biased technical change (RBTC) hypothesis according to which workers performing routine tasks can be easily replaced by machines (mainly computers). They studied how computerisation reshaped the task composition of work and the structure of labour demand in the 1960-1998 period. Autor et al. (2003) introduced a novel methodology to distinguish skills from tasks and defined three main categories of tasks: routine cognitive tasks (e.g. data entry), routine manual tasks (e.g. repetitive production) and non-routine tasks (involving problem-solving, intuition, persuasion, and creativity), subsequently split into: non-routine analytical, non-routine interpersonal and non-routine manual. Their approach was to link the employment data (Census and Current Population Survey job titles) to the Dictionary of Occupational Titles (DOT) $)^{3}$ to quantify the task content of jobs. They found that 'computerization is associated with reduced labor input of routine manual and routine cognitive tasks and increased labor input of non-routine cognitive task' (Autor et al., 2003, p. 1279). An update is provided in Autor and Price (2013) paper analysing changes in the task content of American jobs in the 1960-2009 period.

Importantly, Autor et al. (2003) conceptualised work as a series of tasks - it boosted the research on changes in the task composition of occupations. DOT is being replaced by the O*NET (the Occupational Information Network) ${ }^{4}$ so later studies employed the original Autor et al. (2003) approach to the O*NET data as a primary source of information for the task content of occupations (e.g. Acemoglu \& Autor, 2011; Fortin \& Lemieux, 2016; Hardy et al., 2016a; Hardy et al., 2016b; Keister \& Lewandowski, 2017).

The approach of Autor et al. (2003) was adopted to study other well developed countries, for instance Spitz-Oener (2006) employed the data for workers from Western Germany to describe how skill requirements changed within occupations and how technological change affected labour demand in Germany. Using the survey in which respondents specified what kind of activities they performed on the job (differently from the DOT or O*NET approach where the description of occupations is based on the expert knowledge), she classified activities into five skill categories (Spitz-Oener, 2006): nonroutine analytical tasks (e.g. research); non-routine interactive tasks (e.g. selling), routine cognitive tasks (e.g. calculating); routine manual tasks (e.g. running a machine) and non-routine manual tasks (e.g. housekeeping).

Since then the task approach has been widely adopted, for instance to study the effects of offshoring on different categories of workers (Baumgarten et al., 2013; Becker et al., 2013; Ebenstein, Harrison, McMillan, \& Phillips, 2014) or the polarisation of the labour markets (Autor \& Dorn, 2013; Goos, Manning, \& Salomons, 2014). These recent papers offer an al-

\footnotetext{
${ }^{3}$ DOT is published by the U. S. Department of Labor (http://www.govtusa.com/dot/).

${ }^{4}$ https://www.onetonline.org/
} 
ternative classification of occupations according to their task content and the degree of offshorability. Becker et al. (2013) developed a continuous 'task intensity measure' using direct information from a detailed German survey in which respondents were asked about the tasks they perform on the job and the associated work tools. Each occupation was assigned a number between 0 and 1 which measured its intensity in non-routine and interactive tasks. Similarly, Autor and Dorn (2013), Autor et al. (2015) and Goos, Manning and Salomons (2014) use occupation-specific indices which help to group workers into categories differing in terms of routine content, abstractness and service task importance.

It shall be underlined that while there are numerous studies on the changing task content of jobs in the U.S. or in Western European countries, the case of Central and Eastern Europe (and Poland in particular) has not been so widely explored. The valuable exceptions include the studies by Hardy et al. (2016b) on Poland and Hardy et al. (2016a), Hardy et al. (2018) or Lewandowski (2017) and on Central and East European Countries (CEE) where they adopt Acemoglu and Autor (2011) approach and O*NET data. Lewandowski (2017) and Hardy et al. (2018) argue that contrary to the most advanced economies, the routine cognitive content of jobs has increased in CEE. It means that CEE countries are exposed to RBTC and potential displacement of workers due to technology improvements.

The recent developments (Marcolin et al., 2016) consider the computation of countryspecific routinisation indices which take into account the fact that the task content of jobs varies across countries. Previous studies assumed that the classification of occupations developed for instance for the U.S can be adopted to study labour markets in other countries, like Poland (Hardy et al., 2016b). In the empirical part of the study we will rely on values of the country specific Routine Intensity Indicator provided by OECD in $2017 .{ }^{5}$

Given the scope of this article, we shall relate to the evidence which explicitly used the task approach and differences across occupations to study wage patterns. Krueger (1993) estimated that in the 1980s (1984-1989) workers employed in occupations which required the use of computers earned $10-15 \%$ higher wages. Baumgarten et al. (2013) found that German workers employed in occupations with higher non-routine task content are less exposed to the negative effect of offshoring on wages. Ebenstein et al. (2014) confirmed that the negative effect of offshoring on wages is most pronounced in the case of American workers performing routine tasks. Hence, the task content of jobs undoubtedly affects the wage determination process. Moreover, the low degree of routinisation of a particular job can act as a 'firewall' against the negative impact of offshoring on domestic workers (Becker et al., 2013).

The evidence on wages in Poland based on micro-level datasets (typically from Labour Force Survey or Structure of Earnings survey) focuses mainly on: the explanation of gender wage gaps (Majchrowska \& Strawinski, 2017; Majchrowska \& Strawinski, 2016; Goraus, Tyrowicz, \& Velde, 2017), the role played by regional factors in wage determination (Cieślik \& Rokicki, 2016; Adamchik \& Hyclak, 2017) or institutional factors of wage setting (Magda, Marsden, \& Moriconi, 2016). In the remaining part of the article we intend to fill the gap which refers to the general lack of the evidence concerning the link between wages in Poland and the import intensity of production, estimated in a task-based setting.

\footnotetext{
${ }^{5}$ The author would like to thank Luca Marcolin for sharing the data.
} 


\section{MATERIAL AND METHODS}

For the purpose of the empirical analysis we use sector level indicators of the involvement into global production (measured by GIIP) merged with individual data on hourly wages and other personal characteristics of Polish workers from EU-SILC. ${ }^{6}$ The matching between the micro-level and sectoral statistics is based on the information on the sector of employment of individuals present in EU-SILC data files. Below we describe these two types of data and the composition of our sample.

\section{Sector Level Data on the Import Intensity of Production}

We measure the dependence of sectors on foreign inputs using an index recently elaborated by Timmer et al. (2016) and called Global Import Intensity of Production (GIIP). GIIP is defined as 'the ratio of GVC imports to the value of the final product' (Timmer et al., 2016, p. 4). GIIP can serve as a new measure of production fragmentation which traces the imports needed in all stages of production. Formally, GIIP is computed using world input-output data (from the new WIOD release, November 2016) ${ }^{7}$ which allow to sum 'all imports needed in any stage of production of a final good or service (GVC imports)' and refer it to the value of the final output.

Hence, it is a backward measure of the dependence of domestic production on foreign inputs. As it is computed with input-output information, it is obtainable at the level of industries (sectors) and can then be aggregated to the country level. Importantly, such a measure has a more straightforward interpretation than the indices based on gross exports decomposition (e.g. foreign value added content of exports - Hummels et al., 2001; Matoo, Wang, \& Wei, 2013). For instance, the value of GIIP equal to 0.6 implies that each 1 USD value of the final output depended on (generated) 60 cents of imports related to different stages of production of this final product.

Available data shows that production fragmentation and the rise of GVCs started in the 1980s, accelerated in the 2000s (as documented by Los et al., 2015), was negatively affected by the 2008-2009 crisis and stagnated after 2011 (see Timmer et al., 2016 and the recent evidence based on the 2016 update of WIOD). Despite the recent slowdown, cross-border fragmentation of production still remains an important phenomenon and the dependence of domestic production on imported inputs, used along the whole value chain, is considerable. As reported by Timmer et al. $(2016$, p. 5) the global import intensity of production was on average equal to approx. $30 \%$ in 2014 , compared to $25 \%$ in 2000$)^{8}$. There are significant differences in GIIP across products, e.g. for computers in 2014 the GIIP was equal to $43.9 \%$.

Figure 2 shows the value of GIIP index for Poland (expressed as an index 0-1 where the value of 1 corresponds to $100 \%$ dependence of the final production on imported

\footnotetext{
${ }^{6}$ The data used in this article is a part of a wider database prepared within the research project realised in cooperation with Joanna Wolszczak-Derlacz (work in progress).

${ }^{7}$ WIOD stands for World Input Output Database. The firsts release (2013, see Dietzenbacher et al., 2013 and Timmer et al., 2015 for details) provided time series of input-output data for 40 countries and the period 1995-2011 while the second release (November 2016, see Timmer et al., 2016) covers 43 countries for the period 2000-2014.

${ }^{8}$ The value reported by Timmer et al. (2016) is averaged across all goods produced in the world economy and based on GIIP on 836 production chains of final goods, weighted by their final output levels.
} 
inputs, calculated along all the backward stages of production). The value of GIIP equal to 0.27 places Poland in the middle of European countries in terms of dependence of production on foreign inputs.

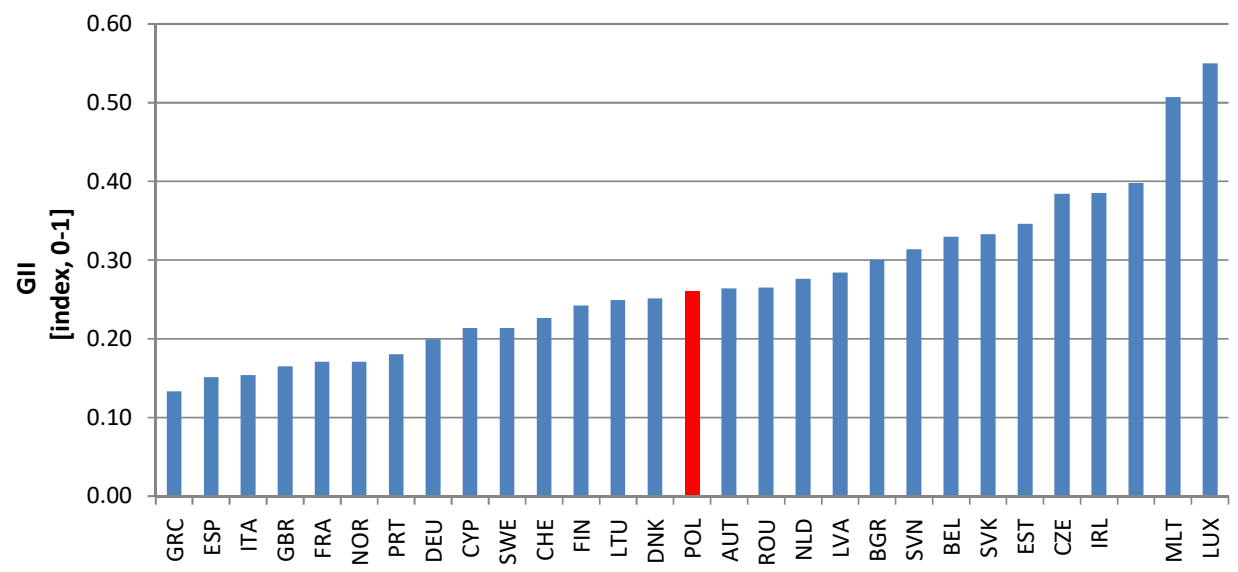

Figure 1. Global Import Intensity of Production - Poland versus other European countries (2014) Source: own elaboration based on WIOD (November 2016 release) and Timmer et al. (2016) methodology.

\section{Microlevel Data and the Sample}

In the present study the EU-SILC serves as a source of information on earnings and personal characteristics important for the wage determination process (such as: gender, age, experience, family status, place of residence etc.). ${ }^{9}$ The EU-SILC provides harmonised micro-level data for several countries (EU member states plus extra-EU countries) and is thus a good source for studies on income and social conditions. ${ }^{10}$ Two types of datasets are available: longitudinal data and cross-sectional data. We use cross-sectional files (personal data, personal register, household data and household register) because some of the variables of interest, e.g. the information on the sector of employment (needed for a merge with sector-level statistics described above), are not provided in longitudinal files.

The years of analysis (2008-2014) are guided by data availability. While choosing the variables we rely on the documentation provided in EC (2014) along with the data files. In the sample we keep only working age individuals (18-65), working full time and for whom the information on occupation, earnings and hours worked is provided. Individuals working in all economy are considered (see the list of industries in Table $1 \mathrm{~A}$ in the Appendix), we drop from the sample only people employed in the armed forces. In the end, the sample encompasses over 60.000 Polish workers (the number of observations in the regression is a bit lower due to joint availability of the data). The empirical results will be weighted by personal cross-sectional weights provided by EU-SILC.

\footnotetext{
${ }^{9}$ The description of the EU-SILC database, along with the country and variables coverage and a complete documentation can be found at: http://ec.europa.eu/eurostat/web/microdata/european-union-statistics-on-income-and-living-conditions. The routines to transform original csv files into the Stata format come from Gesis (prepared by Heike Wirth, http://www.gesis.org/en/missy/materials/EU-SILC/setups).

${ }^{10}$ The description of the EU-SILC potential for the purpose of research applications can be found in Berger and Schaffner (2016). Iacpovou (2012) discuss issues concerning the use of EU-SILC for cross-national analysis.
} 
The main variable of interest - hourly wage - is computed for every individual on the base of the information on yearly income and the number of months in full-time job, combined with the average number of hours worked per week. ${ }^{11}$ In order to minimise the influence of outliers and potentially misreported earnings data, we do the correction at the top and at the bottom of the wage distribution. ${ }^{12}$ Wages are reported into the real terms with the use of harmonised index of consumer prices.

In the wage regressions we will additionally use individual level information on: sex, age, job experience (number of years spent in paid work), family status (information if living with a partner) ${ }^{13}$, education (primary, secondary, tertiary $)^{14}$, firm characteristics (firm size: micro, medium or big ${ }^{15}$ ), type of job contract (temporary or permanent), managerial position, the sector of employment (NACE Rev.2, 2 digit code), country and region of the residence (NUTS 1). All of these variables come from EU-SILC.

Importantly, EU-SILC cross-sectional files provide information on workers' occupation (according to ISCO-88 2 digit level). ${ }^{16}$ It allows us to match micro-level data on Polish workers with new country-specific indices of routine content from OECD (Marcolin et al., 2016).We will use this numeric index in the estimations. In the descriptive part, we will additionally employ the classification by Goos et al. (2014) to assign workers to different occupational categories. These are: Rout - highly routine, low in abstractness and service task importance, Serv - low in routine and abstractness, high in service task importance, AbServ- low in routine, high in abstractness and service task importance. They differ in the degree of abstractness, routines and service task importance. ${ }^{17}$

\footnotetext{
${ }^{11}$ Alternatively, the approach of Schäfer and Gottschall $(2015$, p. 477) could be used 'monthly gross earnings are the basis for calculating hourly earnings by multiplying the weekly working hours by 4.2 and dividing the monthly gross earnings by the resulting monthly working hours'. However, such a method of calculation is more crude. The correlation between the two series of hourly wages, obtained using our approach and the one of Schäfer and Gottschall (2015) equals to 0.66.

${ }^{12}$ At the bottom, the distribution is trimmed at the $1 / 100$ of mean, at the top wages greater than ten times the national median are set to ten times the national median. Additionally, hourly wage values below the 1st and above the 99th percentile of country and year specific wage distribution are set to be equal to the 1 st and 99th percentile, respectively.

${ }^{13}$ Such information is used instead of a conventional dummy for married people (based on the variable PB190) because, as stated in the documentation (EC, 2014, p. 256): 'Marital status is the conjugal status of each individual in relation to the marriage laws of the country (i.e. de jure status). It therefore does not necessarily correspond with the actual situation of the household in terms of co-habitation, arrangements, etc.'. Specifically, we use the variable PB200 - Consensual Union ('with or without a legal basis, where the consensual union with a legal basis includes both married couples and registered partners, (..) both partners have to live in the same household.' - EC, 2014, p. 257).

${ }^{14}$ We reclassify variable PEO40 (the highest ISCED level attained) which includes 9 categories of educational attainment into three broader groups: primary, secondary and tertiary education (for details see EC, 2014, p. 265). ${ }^{15}$ We reclassify variable PL130 (Number of persons working at the local unit) to get three categories of companies: micro (<11 persons working), medium (11-49) and big (=>50).

${ }^{16}$ International Standard Classification of Occupations: http://www.ilo.org/public/english/bureau/stat/ isco/isco08/index.htm

${ }^{17}$ Due to space limits, the mapping between occupations and task categories is available upon request.
} 


\section{FINDINGS AND DISCUSSION}

\section{Descriptive Evidence}

Concerning the wage level, it is evident that there are significant wage differences across types of occupations in Poland, given their task content. This is in line with similar evidence shown for other countries (Autor, 2013; Autor \& Price, 2013; Baumgarten et al., 2013). Table 1 reports that Polish workers employed in occupations which require relatively high ability to perform tasks low in routine, but high in abstractness and service task importance (AbServ category) earn considerably more than the other two categories (Serv and Rout).

Table 1. Average values of hourly wage according to the type of occupation

\begin{tabular}{|c|c|c|c|}
\hline Year & AbServ & Rout & Serv \\
\hline 2008 & 4.8 & 3.1 & 2.5 \\
\hline 2009 & 5.8 & 3.5 & 2.9 \\
\hline 2010 & 4.9 & 3.0 & 2.5 \\
\hline 2011 & 5.4 & 3.3 & 2.8 \\
\hline 2012 & 5.5 & 3.4 & 2.8 \\
\hline 2013 & 5.5 & 3.5 & 2.9 \\
\hline 2014 & 5.6 & 3.5 & 2.9 \\
\hline
\end{tabular}

Note: occupation categories based on Goos et al. (2014). Sample: 60,287 Polish workers. Values weighted by personal cross-sectional weights.

Source: own calculations based on EU-SILC data.

From the point of view of our primary aim, it is important to assess the link between the level of wages paid in a particular occupation, the degree of its routinisation and the dependence of sector on foreign inputs. In Table 2 we report the coefficients of correlation between these three variables present in our dataset. Hourly wage $(w)$ is negatively correlated with RTI and with GIIP. In our sample in 2014 the coefficients of correlation equal to -0.3 and -0.07 , respectively. The values computed for the whole analysed period (2008-2014) are similar: -0.3 and -0.08 , respectively. In other words: wages in occupations with higher routine content and in sectors more dependent on foreign inputs (with higher import intensity of production) are typically lower. The latter relationship, however, is weak. Interestingly, relatively high positive correlation between the index of routinisation and GIIP (0.47) suggests that Polish sectors which value chain of production relies intensively on foreign inputs, use labour force employed in routine intensive occupations. This finding is linked to the structure of Polish employment and its general routinisation (Hardy et al., 2016).

So far, no other individual level or industry level characteristics have been taken into account as determinants of wages. Hence, in the next step we will check if the global import intensity of production and the task requirements are significant predictors of wages of Polish workers, once all the other dimensions of the wage determination process are accounted for. 
Table 2. Correlation coefficients between w, RTI and GIIP

\begin{tabular}{|c|c|c|c|}
\hline \multicolumn{4}{|c|}{$2014(n=8489)$} \\
\hline Category & Hourly wage (w) & Routinisation index (RTI) & $\begin{array}{l}\text { Global Import Intensity } \\
\text { of Production (GIIP) }\end{array}$ \\
\hline Hourly wage (w) & 1.0000 & & \\
\hline RTI & $-0.3072^{*}$ & 1.0000 & \\
\hline GIIP & $-0.0726 *$ & $0.4780^{*}$ & 1.0000 \\
\hline \multicolumn{4}{|c|}{$2008-2014(n=60287)$} \\
\hline Category & Hourly wage (w) & Routinisation index (RTI) & $\begin{array}{c}\text { Global Import Intensity of } \\
\text { Production (GIIP) }\end{array}$ \\
\hline Hourly wage (w) & 1.0000 & & \\
\hline RTI & $-0.3113^{*}$ & 1.0000 & \\
\hline GIIP & $-0.0854 *$ & $0.4641^{*}$ & 1.0000 \\
\hline
\end{tabular}

Note: occupation categories based on Goos et al. (2014). Sample: Polish workers (n observations). Values weighted by personal cross-sectional weights.

Source: own calculations based on data from EU-SILC, WIOD and OECD (data described in the main text).

\section{The Model}

Using the micro-level and industry level data described in Section 2, we estimate an augmented version of Micer-type wage regression model (Mincer \& Polachek, 1974; Heckman et al., 2006):

$$
\begin{gathered}
\text { lnw }_{i j o r t ~}=\alpha+\beta_{1} \text { Demog }_{i t}+\beta_{2} J_{o b}+\beta_{3} G I I P_{j t}+ \\
+\beta_{4} R T I_{o i} * G I I P_{j t}+\beta_{6} \ln I N D_{j t}+D_{j}+D_{r}+D_{t}+\varepsilon_{i j o r t}
\end{gathered}
$$

where:

$i$ - denotes an individual (a worker) employed in occupation $o$ in sector $j$ and living in region $r$ at time $t$ (here the model is estimated only for workers from one country, Poland, so the country subscript is omitted).

Hence, the model is estimated linking microdata on workers and more aggregated sector (industry) level data on involvement into global production - similar approach has been adopted by Baugmarten et al. (2013).

Hourly wage $(w)$ is assumed to be determined by a set of individual characteristics called Demog which include personal characteristics (sex, information on a family status, age and age squared or experience and experience squared ${ }^{18}$, education) and job characteristics called Job (firm size, type of contract, supervisory position) - all described in Section 2. Sector, region and time specific effects are captured through the inclusion of dummy variables, additionally we control for the industry value added (IND) which captures the effect of potentially lower wages in sectors with negligible value added content.

The crucial variables of interest are: GIIP, RTI, as well as their interaction. GIIP measures global import intensity of production typical for the sector of employment $j$, while $R T I$ refers to the routinisation level (task requirements) in occupation performed

\footnotetext{
${ }^{18}$ The correlation between age and job experience in our sample is equal to 0.93 , hence we decided to use these variables in separate specifications.
} 
by individual $i$. In specifications employing GIIP, the model is estimated using IV (instrumental variables) estimator (with lags of GIIP used as instruments ${ }^{19}$ ), with robust standard errors. Personal cross-sectional weights are used.

\section{Estimation Results}

The first set of results is reported in Table 3. For comparison, the first two columns in the table refers to basic Mincer-type estimation with individual level characteristics, as well as country and industry dummies (GIIP is not yet taken into account). Given high correlation between age and experience, they do not enter into the estimation simultaneously. In line with the expectations, hourly wage is higher for males and persons having family (living with a partner), is positively correlated with longer job experience and higher education level. There is a positive but nonlinear relationship between hourly wage and both the age of the workers (column 1) and their experience (column 2). Polish workers employed in bigger firms, having permanent contract and performing supervisory work earn more. Hence, all the basic wage determinants, referring to individual dimension of wage determination, have the expected signs and are statistically significant. These findings are perfectly in line with the literature using the Mincerian approach to study wage determinants (Mincer \& Polachek, 1974).

In columns (3) and (4) we report the results of IV estimation with additional explanatory variable: GIIP (in bold). The dependence of the sector of employment on foreign inputs, measured by global import intensity of production, results to be negatively related to wages. The estimated coefficient equals to approx. -0.35 and is statistically significant. It means that, once all the other controls are taken into account, the increase in GIIP by $1 \%$ is associated with a downward pressure on wages of Polish workers by $0.35 \%$.

Now the question is to what extent this result depends on the category of workers given the tasks typical for their occupation. Is the relationship between wages and GIIP stronger in the case of routine intensive occupations (with higher RTI index)?

In Table 4 we report the results referring to the specification which incorporates the index of occupational routinisation $R T I$ (columns 1 and 2). Again, all the variables traditionally present in the Mincerian model have coefficients of expected signs and are statistically significant. The estimated $R T I$ coefficient is negative $(-0.12)$ and statistically significant: unsurprisingly the higher the routinisation of the occupation, the lower the wage.

\footnotetext{
${ }^{19}$ See Parteka and Wolszczak-Derlacz (2017) for the application of an alternative instrumental strategy - based on the gravity approach (in the spirit of Frankel and Romer, 1999). It was not adopted here due to data constraints (GII measurement requires the loop over all the backward tiers of production in the global value chain).
} 
Table 3. Estimation results (1)

\begin{tabular}{|c|c|c|c|c|}
\hline Variable / Measure & (1) & (2) & (3) & (4) \\
\hline \multirow[t]{2}{*}{ Sex (=1 if male) } & $0.140 * * *$ & $0.129 * * *$ & $0.140 * * *$ & $0.130 * * *$ \\
\hline & {$[0.005]$} & {$[0.005]$} & {$[0.005]$} & {$[0.005]$} \\
\hline \multirow[t]{2}{*}{ Age (year) } & $0.035 * * *$ & & $0.034 * * *$ & \\
\hline & {$[0.002]$} & & {$[0.002]$} & \\
\hline \multirow[t]{2}{*}{ Age $^{2}$} & $-0.000 * * *$ & & $-0.000 * * *$ & \\
\hline & {$[0.000]$} & & {$[0.000]$} & \\
\hline \multirow[t]{2}{*}{ Experience (years in paid job) } & & $0.022 * * *$ & & $0.022 * * *$ \\
\hline & & {$[0.001]$} & & {$[0.001]$} \\
\hline \multirow[t]{2}{*}{ Experience $^{2}$} & & $-0.000 * * *$ & & $-0.000 * * *$ \\
\hline & & {$[0.000]$} & & {$[0.000]$} \\
\hline \multirow{2}{*}{ Education (=1 if tertiary or higher) } & $0.583^{* * *}$ & $0.593 * * *$ & $0.556 * * *$ & $0.567^{* * *}$ \\
\hline & {$[0.012]$} & {$[0.012]$} & {$[0.013]$} & {$[0.013]$} \\
\hline \multirow[t]{2}{*}{ Education (=1 if secondary) } & $0.156^{* * *}$ & $0.145^{* * *}$ & $0.147 * * *$ & $0.137^{* * *}$ \\
\hline & {$[0.010]$} & {$[0.010]$} & {$[0.011]$} & {$[0.011]$} \\
\hline \multirow[t]{2}{*}{ Partner (=1 if living with a partner) } & $0.040 * * *$ & $0.038 * * *$ & $0.040 * * *$ & $0.038 * * *$ \\
\hline & {$[0.006]$} & {$[0.006]$} & {$[0.006]$} & {$[0.006]$} \\
\hline \multirow[t]{2}{*}{ Firm size - big (=1 if >49 employees) } & $0.203^{* * *}$ & $0.201 * * *$ & $0.235^{* * *}$ & $0.232 * * *$ \\
\hline & {$[0.007]$} & {$[0.007]$} & {$[0.008]$} & {$[0.008]$} \\
\hline \multirow[t]{2}{*}{ Firm size - medium (=1 if 11-49 employees) } & $0.081 * * *$ & $0.079 * * *$ & $0.110 * * *$ & $0.107 * * *$ \\
\hline & {$[0.007]$} & {$[0.007]$} & {$[0.008]$} & {$[0.008]$} \\
\hline \multirow[t]{2}{*}{ Contract (=1 if permanent) } & $0.180 * * *$ & $0.168 * * *$ & $0.173 * * *$ & $0.161^{* * *}$ \\
\hline & {$[0.006]$} & {$[0.006]$} & [0.006] & {$[0.006]$} \\
\hline \multirow[t]{2}{*}{ Manager (=1 if supervisory position) } & $0.179 * * *$ & $0.175^{* * *}$ & $0.181 * * *$ & $0.177^{* * *}$ \\
\hline & {$[0.007]$} & {$[0.007]$} & {$[0.007]$} & {$[0.007]$} \\
\hline \multirow[t]{2}{*}{ InIND } & $-0.042 * * *$ & $-0.040 * * *$ & $-0.037 * * *$ & $-0.035^{* * *}$ \\
\hline & {$[0.004]$} & {$[0.004]$} & {$[0.005]$} & {$[0.005]$} \\
\hline \multirow[t]{2}{*}{ GIIP } & & & $-0.359 * * *$ & $-0.346 * * *$ \\
\hline & & & {$[0.065]$} & {$[0.065]$} \\
\hline \multirow[t]{2}{*}{ cons } & $0.405^{* * *}$ & $1.002 * * *$ & $0.420 * * *$ & $0.990^{* * *}$ \\
\hline & {$[0.072]$} & {$[0.063]$} & {$[0.080]$} & {$[0.070]$} \\
\hline R2 & 0.33 & 0.33 & $(0.34)$ & $(0.34)$ \\
\hline $\mathrm{N}$ & 55570 & 55470 & 46884 & 46831 \\
\hline Hansen J statistic ( $p$-val) & & & 0.00 & 0.00 \\
\hline Sector dummy & yes & yes & yes & yes \\
\hline Region dummy & yes & yes & yes & yes \\
\hline Time dummy & yes & yes & yes & yes \\
\hline
\end{tabular}

Notes: Personal cross-sectional weights used. Robust standard errors in parentheses, statistically significant at $* * * 1, * * 5, * 10$ percent level. Education- primary education set as default category, firm size -small size (1-10) set as default category. (1) and (2) - OLS, (3) and (4) - IV.

Source: own calculations in Stata. 
Table 4. Estimation results (2)

\begin{tabular}{|c|c|c|c|c|}
\hline Variable / Measure & (1) & (2) & (3) & (4) \\
\hline \multirow[t]{2}{*}{ Sex (=1 if male) } & $0.159 * * *$ & $0.148^{* * *}$ & $0.145 * * *$ & $0.134 * * *$ \\
\hline & {$[0.005]$} & {$[0.005]$} & {$[0.005]$} & {$[0.005]$} \\
\hline \multirow[t]{2}{*}{ Age (year) } & $0.037 * * *$ & & $0.036 * * *$ & \\
\hline & {$[0.002]$} & & {$[0.002]$} & \\
\hline \multirow[t]{2}{*}{$\mathrm{Age}^{2}$} & $-0.000 * * *$ & & $-0.000 * * *$ & \\
\hline & {$[0.000]$} & & {$[0.000]$} & \\
\hline \multirow[t]{2}{*}{ Experience (years in paid job) } & & $0.023 * * *$ & & $0.023 * * *$ \\
\hline & & {$[0.001]$} & & {$[0.001]$} \\
\hline \multirow[t]{2}{*}{ Experience $^{2}$} & & $-0.000 * * *$ & & $-0.000 * * *$ \\
\hline & & {$[0.000]$} & & {$[0.000]$} \\
\hline \multirow[t]{2}{*}{ Education (=1 if tertiary or higher) } & $0.477 * * *$ & $0.489 * * *$ & $0.507 * * *$ & $0.518^{* * *}$ \\
\hline & {$[0.012]$} & {$[0.012]$} & {$[0.013]$} & {$[0.013]$} \\
\hline \multirow[t]{2}{*}{ Education (=1 if secondary) } & $0.121 * * *$ & $0.110^{* * *}$ & $0.130 * * *$ & $0.119^{* * *}$ \\
\hline & [0.010] & {$[0.010]$} & {$[0.011]$} & {$[0.011]$} \\
\hline \multirow[t]{2}{*}{ Partner (=1 if living with a partner) } & $0.035^{* * *}$ & $0.034 * * *$ & $0.037^{* * *}$ & $0.035^{* * *}$ \\
\hline & {$[0.006]$} & {$[0.006]$} & {$[0.006]$} & {$[0.006]$} \\
\hline \multirow[t]{2}{*}{ Firm size - big (=1 if >49 employees) } & $0.203 * * *$ & $0.201 * * *$ & $0.237 * * *$ & $0.234 * * *$ \\
\hline & {$[0.006]$} & {$[0.006]$} & {$[0.007]$} & {$[0.007]$} \\
\hline \multirow[t]{2}{*}{ Firm size - medium (=1 if 11-49 employees) } & $0.079 * * *$ & $0.078 * * *$ & $0.112 * * *$ & $0.109 * * *$ \\
\hline & {$[0.007]$} & {$[0.007]$} & {$[0.008]$} & {$[0.008]$} \\
\hline \multirow[t]{2}{*}{ Contract (=1 if permanent) } & $0.163^{* * *}$ & $0.152 * * *$ & $0.164 * * *$ & $0.153^{* * *}$ \\
\hline & [0.006] & {$[0.006]$} & {$[0.006]$} & [0.006] \\
\hline \multirow[t]{2}{*}{ Manager (=1 if supervisory position) } & $0.133 * * *$ & $0.130 * * *$ & $0.156 * * *$ & $0.152^{* * *}$ \\
\hline & {$[0.007]$} & {$[0.007]$} & {$[0.007]$} & {$[0.007]$} \\
\hline \multirow[t]{2}{*}{ InIND } & $-0.043 * * *$ & $-0.042 * * *$ & $-0.039 * * *$ & $-0.037 * * *$ \\
\hline & {$[0.004]$} & {$[0.004]$} & {$[0.005]$} & {$[0.005]$} \\
\hline \multirow[t]{2}{*}{\begin{tabular}{|l} 
RTI \\
\end{tabular}} & $-0.122 * * *$ & $-0.120 * * *$ & & \\
\hline & {$[0.004]$} & {$[0.004]$} & & \\
\hline \multirow[t]{2}{*}{ GIIP } & & & $-0.414 * * *$ & $-0.399 * * *$ \\
\hline & & & {$[0.065]$} & {$[0.064]$} \\
\hline \multirow[t]{2}{*}{ RTI*GIIP } & & & $-0.204 * * *$ & $-0.202 * * *$ \\
\hline & & & {$[0.011]$} & {$[0.011]$} \\
\hline \multirow[t]{2}{*}{ cons } & $0.503 * * *$ & $1.130 * * *$ & $0.483^{* * *}$ & $1.080^{* * *}$ \\
\hline & {$[0.071]$} & {$[0.062]$} & {$[0.080]$} & {$[0.070]$} \\
\hline R2 & 0.35 & 0.35 & $(0.34)$ & $(0.35)$ \\
\hline $\mathrm{N}$ & 55570 & 55470 & 46884 & 46831 \\
\hline Hansen J statistic (p-val) & & & 0.00 & 0.00 \\
\hline Sector dummy & yes & yes & yes & yes \\
\hline Region dummy & yes & yes & yes & yes \\
\hline Time dummy & yes & yes & yes & yes \\
\hline
\end{tabular}

Notes: Personal cross-sectional weights used. Robust standard errors in parentheses, statistically significant at $* * * 1, * * 5, * 10$ percent level. Education- primary education set as default category, firm size -small size (1-10) set as default category. (1) and (2) - OLS, (3) and (4) - IV.

Source: own calculations in Stata. 
It is important to check if the result of negative relationship between GIIP and wages is conditional upon the type of tasks performed on the job. Columns (3) and (4) refer to the full specification of the model (1) with GIIP and the interaction term between RTI and GIIP. Here, the model is estimated with the use of instrumental variables method (GIIP is instrumented), so potential endogeneity between wages and involvement into global production is taken into account. The result is that wages of Polish workers are negatively associated with the global import intensity of production (coefficient $=-0.4$ ) but importantly, given that the coefficient associated with the interaction term (GI/*RTI) is significant and negative $(-0.2)$, this effect depends also on the task content of the occupation. For Polish workers employed in occupations characterised by high routinisation level (hence, with high $R T I$ index). For instance, in the case of assemblers (one of the typically offshored jobs), $R T I=1.78$, so it is one of the most routinised occupations in the Polish economy. According to the estimation results reported in Column 3, 1\% increase in GIIP would result in $0.75 \%$ downward pressure on their hourly wage $[-0.4+(-0.2) * 1.78=-0.756]$. This effect is more than two time stronger then when the routinisation of the occupation was not taken into consideration (Table 1).

These findings are in line with the evidence for other countries (e.g. Germany examined by Baumgarten et al., 2013, pp. 143-144: 'We find a pronounced negative wage effect of cross-industry offshoring that is inversely related to the interactivity and non-routine content of workers' occupations').

\section{CONCLUSIONS}

The literature review revealed that while there is an extensive task-based evidence on the effects of fragmentation on workers in the U.S. or in well-developed European countries (e.g. Germany or Denmark), the evidence for less developed countries, Poland in particular, is much scarcer. We do have evidence on the change in the observed changes in the task composition of jobs in Central and Eastern Europe, including Poland (Hardy et al., 2016; Keister \& Lewandowski, 2017). However, the relationship between wages in Poland and the reliance on foreign inputs has not yet been studied from the micro-level task-based perspective.

The main aim of this article was to find out if wages of Polish workers are determined by the degree their sectors of employment depend on foreign production. To this aim, we estimated an empirical model of wage determination in which, in addition to typical individual characteristic (in the spirit of the Mincerian wage model), a measure of global import intensity of Polish production was included. The adopted task-based approach allowed a proper distinction between different types of occupations according to their routinisation level and offshoring potential. Importantly, two significant improvements, with respect to the existing empirical literature should be underlined: the use of country specific routinisation indices and the backward measurement of the import intensity of production along the whole value chain.

Descriptive evidence based on the EU-SILC data proves that wages of Polish workers differ across occupations with different routinisation level. Unsurprisingly, the higher the routine content of jobs, the lower the wage. Regression results show that occupations with higher routine content experience stronger downward pressure on wages exhibited by intensive dependence on imported inputs. Hence, not all the workers are affected by 
global production fragmentation in the same way. The level of routinisation matters when estimating the relationship between the dependence on foreign intermediates and the level of wages in Poland. It has important policy implications for the perception of labour market consequences of the involvement into global value chains. Future work could involve the comparison of the Polish case with the one typical for workers from other countries from Central and Eastern Europe. Time-varying and country-specific measurement of the task content of jobs is also an important (and non-trivial) issue to be solved.

\section{REFERENCES}

Acemoglu, D., \& Autor, D. (2011). Skills, tasks and technologies: Implications for employment and earnings. In O. Ashenfelter \& D.E. Card (Eds.), Handbook of Labor Economics, 4 (pp. 1043-1171), Amsterdam: Elsevier.

Adamchik, V.A., \& Hyclak, T.J. (2017). Economic Transition and Regional Wages: The Evidence from Poland. Journal Transition Studies Review, 24(1), 47-69.

Autor, D., Levy, F., \& Murnane, R. (2003). The skill content of recent technological change: an empirical exploration. Quarterly Journal of Economics, 118(4), 1279-1333.

Autor, D.H., \& Dorn, D. (2013). The growth of low-skill service jobs and the polarization of the US labor market. The American Economic Review, 103(5), 1553-1597. https://doi.org/10.1257/aer.103.5.1553

Autor, D. (2013). The 'task approach' to labor markets: an overview. Journal for Labour Market Research, 46(3), 185-199.

Autor, D.H., \& Handel, M.J. (2013). Putting tasks to the test: Human capital, job tasks, and wages. Journal of Labor Economics, 31(S1), S59-S96. https://doi.org/10.1086/669332

Autor, D.H., \& Price, B. (2013). The changing task composition of the US labor market: An update of Autor, Levy, \& Murnane (2003). (MIT Working Paper). Retrieved on February 12, 2018 from https://economics.mit.edu/files/9758

Autor, D.H., Dorn, D., \& Hanson, G.H. (2015). Untangling Trade and Technology: Evidence from Local Labour Markets. Economic Journal, 125(584), 621-646. https://doi.org/10.1111/ecoj.12245

Baldwin, R., \& Robert-Nicoud, F. (2014). Trade-in-goods and trade-in-tasks: An integrating framework. Journal of International Economics, 92(1), 51-62.

Baumgarten, D., Geishecker, I., \& Görg, H. (2013). Offshoring, tasks, and the skill-wage pattern. European Economic Review, 61, 132-152.

Becker, S.O., \& Muendler, M.A. (2015). Trade and tasks: an exploration over three decades in Germany. Economic Policy, 30(84), 589-641.

Becker, S.O., Ekholm, K., \& Muendler, M.A. (2013). Offshoring and the onshore composition of tasks and skills. Journal of International Economics, 90(1), 91-106.

Berger, M., \& Schaffner, S. (2016). A note on how to realize the full potential of the EU-SILC data. Journal of Economic and Social Measurement, 41(4), 395-416.

Cieślik, A., \& Rokicki, B. (2016). Individual wages and regional market potential. Economics of Transition, 24(4), 661-682. https://doi.org/10.1111/ecot.12102

Costinot, A., Vogel, J., \& Wang, S. (2012). An elementary theory of global supply chains. Review of Economic Studies, 80(1), 109-144

Dietzenbacher, E., Los, B., Stehrer, R., Timmer, M., \& De Vries, G. (2013). The construction of world input-output tables in the WIOD project. Economic Systems Research, 25(1), 71-98. 
Ebenstein, A., Harrison, A., McMillan, M., \& Phillips, S. (2014). Estimating the impact of trade and offshoring on American workers using the current population surveys. Review of Economics and Statistics, 96(4), 581-595.

EC (2014). Methodological guidelines and description of EU-SILC target variables. 2014 operation (Version October 2014). DocSILC065 (2014 operation).

Feenstra, R., \& Hanson, G. (2001). Global production sharing and rising inequality: A survey of trade and wages (NBER Working Paper No. 8372). National Bureau of Economic Research.

Fortin, N., \& Lemieux, T. (2016). Inequality and Changes in Task Prices: Within and between Occupation Effects. In Inequality: Causes and Consequences (pp. 195-226). Emerald Group Publishing Limited.

Frankel, J.A., \& Romer, D.H. (1999). Does trade cause growth?. American Economic Review, 89(3), 379-399.

Goos, M., Manning, A., \& Salomons, A. (2014). Explaining job polarization: Routine-biased technological change and offshoring. The American Economic Review, 104(8), 2509-2526.

Goraus, K., Tyrowicz, J., \& Velde, L. (2017). Which Gender Wage Gap Estimates to Trust? A Comparative Analysis. Review of Income and Wealth, 63(1), 118-146.

Grossman, G.M., \& Rossi-Hansberg, E. (2008). Trading tasks: A simple theory of offshoring. The American Economic Review, 98(5), 1978-1997.

Grossman, G.M., \& Rossi-Hansberg, E. (2012). Task trade between similar countries. Econometrica, 80(2), 593-629.

Hardy, W., Keister, R., \& Lewandowski, P. (2016a). Technology or Upskilling? Trends in the Task Composition of Jobs in Central and Eastern Europe. IBS Working Paper Series, Institute of Structural Research (IBS). (HKUST IEMS Working Paper No. 2016-40). Retrieved on February 12, 2018 from http://ibs.org.pl/en/publications/technology-or-upskilling-trends-in-the-taskcomposition-of-jobs-in-central-and-eastern-europe/

Hardy, W., Keister, R., \& Lewandowski, P. (2016b). Do entrants take it all? The evolution of task content of jobs in Poland. Ekonomia. Rynek, Gospodarka, Społeczeństwo, 47(2016), 23-50.

Hardy, W., Keister, R., \& Lewandowski, P. (2018). Educational upgrading, structural change and the task composition of jobs in Europe. Economics of Transition, 26(2), 201-231.

Heckman, J.J., Lochner, L.J., \& Todd, P.E. (2006). Earnings functions, rates of return and treatment effects: The Mincer equation and beyond. Handbook of the Economics of Education, 1, 307-458.

Hummels, D., Ishii, J., \& Yi, K.M. (2001). The nature and growth of vertical specialization in world trade. Journal of International Economics, 54(1), 75-96.

lacovou, M., Kaminska, O., \& Levy, H. (2012). Using EU-SILC data for cross-national analysis: strengths, problems and recommendations (ISER Working Paper Series No. 2012-03).

Johnson, R.C., \& Noguera, G. (2012). Accounting for intermediates: Production sharing and trade in value added. Journal of International Economics, 86(2), 224-236.

Johnson, R.C., \& Noguera, G. (2016). A portrait of trade in value added over four decades (NBER Working Paper No. 22974), National Bureau of Economic Research.

Keister, R., \& Lewandowski, P. (2017). A routine transition in the digital era? The rise of routine work in Central and Eastern Europe. Transfer: European Review of Labour and Research, 23(3), 263279. https://doi.org/10.1177/1024258917703557

Koopman, R., Wang, Z., \& Wei, S.J. (2014). Tracing value-added and double counting in gross exports. The American Economic Review, 104(2), 459-494.

Krueger, A.B. (1993). How Computers Have Changed the Wage Structure: Evidence from Microdata, 1984-1989. The Quarterly Journal of Economics, 33-60. 
Los, B., Timmer, M.P., \& Vries, G.J. (2015). How global are global value chains? A new approach to measure international fragmentation. Journal of Regional Science, 55(1), 66-92.

Magda, I., Marsden, D., \& Moriconi, S. (2016). Lower coverage but stronger unions? Institutional changes and union wage premia in Central Europe. Journal of Comparative Economics, 44(3), 638-656.

Majchrowska, A., \& Strawiński, P. (2016). Regional Differences in Gender Wage Gaps in Poland: New Estimates Based on Harmonized Data for Wages. Central European Journal of Economic Modelling and Econometrics, 8(2), 115-141.

Majchrowska, A., \& Strawiński, P. (2017). Impact of minimum wage increase on gender wage gap: Case of Poland. Economic Modelling (in press). Retrieved on February 12, 2018 from https://doi.org/10.1016/j.econmod.2017.10.021

Marcolin, L., Miroudot, S., \& Squicciarini, M. (2016). The routine content of occupations: new crosscountry measures based on PIAAC. OECD Science, Technology and Industry Working Papers, 2016(2). https://doi.org/10.1787/5jm0q1dhszjg-en

Mattoo, A., Wang, Z., \& Wei, S.J. (2013). Trade in value added: developing new measures of crossborder trade (World Bank Publications No. 15809). Washington: The World Bank.

Mincer, J., \& Polachek, S. (1974). Family investments in human capital: Earnings of women. Journal of Political Economy, 82(2, Part 2), S76-S108.

Schäfer, A., \& Gottschall, K. (2015). From wage regulation to wage gap: how wage-setting institutions and structures shape the gender wage gap across three industries in 24 European countries and Germany. Cambridge Journal of Economics, 39(2), 467-496. https://doi.org/10.1093/cje/bev005

Spitz-Oener, A. (2006). Technical change, job tasks, and rising educational demands: looking outside the wage structure. Journal of Labor Economics, 24(2), 235-270.

Timmer, M.P., Dietzenbacher, E., Los, B., Stehrer, R., \& de Vries, G.J. (2015). An Illustrated User Guide to the World Input-Output Database: the Case of Global Automotive Production. Review of International Economics, 23, 575-605. https://doi.org/10.1111/roie.12178

Timmer, M.P., Erumban, A.A., Los, B., Stehrer, R., \& de Vries, G.J. (2014). Slicing up global value chains. The Journal of Economic Perspectives, 28(2), 99-118.

Timmer, M.P., Los, B., Stehrer, R., \& de Vries, G.J. (2016). An Anatomy of the Global Trade Slowdown based on the WIOD 2016 Release (GGDC research memorandum number 162), University of Groningen.

Wood, A. (1995). How trade hurt unskilled workers. The Journal of Economic Perspectives, 9(3), 57-80. WTO (2017). World Trade Report 2017. Trade, technology and jobs. Geneva: World Trade Organisation. 
Appendix A: List of industries

\begin{tabular}{|c|l|}
\hline $\begin{array}{c}\text { NACE rev.2 } \\
\text { section }\end{array}$ & \multicolumn{1}{|c|}{ Description } \\
\hline $\mathrm{a}$ & agriculture, forestry and fishing \\
\hline $\mathrm{b}-\mathrm{e}$ & $\begin{array}{l}\text { mining and quarrying, manufacturing, electricity, gas, steam and air conditioning sup- } \\
\text { ply; water supply; sewerage, waste management and remediation activities }\end{array}$ \\
\hline $\mathrm{f}$ & construction \\
\hline $\mathrm{g}$ & wholesale and retail trade; repair of motor vehicles and motorcycles \\
\hline $\mathrm{h}$ & transportation and storage \\
\hline $\mathrm{i}$ & accommodation and food service activities \\
\hline $\mathrm{j}$ & information and communication \\
\hline $\mathrm{k}$ & financial and insurance activities \\
\hline $\mathrm{l}-\mathrm{n}$ & $\begin{array}{l}\text { real estate activities; professional, scientific and technical activities; administrative } \\
\text { and support service activities }\end{array}$ \\
\hline $\mathrm{o}$ & public administration and defence; compulsory social security \\
\hline $\mathrm{p}$ & education \\
\hline $\mathrm{q}$ & human health and social work activities \\
\hline $\mathrm{r}-\mathrm{u}$ & $\begin{array}{l}\text { arts, entertainment and recreation; other service activities; activities of households } \\
\text { as employers; undifferentiated goods- and services-producing activities of house- } \\
\text { holds for own use; activities of extraterritorial organisations and bodies }\end{array}$ \\
\hline
\end{tabular}

Source: own elaboration based on EC (2014), pp. 384-387. 


\section{Author}

\section{Aleksandra Parteka}

Associate professor (with habilitation in economics) at the Faculty of Management and Economics, Gdansk University of Technology (Gdansk, Poland). Her research interests include: international trade, economic integration, trade-labour market interactions, productivity and efficiency analysis.

Correspondence to: Gdansk University of Technology, Faculty of Management and Economics, Narutowicza 11/12, 80-233 Gdansk, Poland; e-mail: aparteka@zie.pg.gda.pl

\section{Acknowledgements and Financial Disclosure}

The research has been conducted within the project financed by the National Science Centre (NCN - Narodowe Centrum Nauki), Poland (decision number DEC-2015/19/B/HS4/02884). The access to EU-SILC data has been granted by the Eurostat under the grant agreement 64/2013-LFS-EU-SILCSES. The author would like to thank Joanna Wolszczak-Derlacz for leading the project and for input in the database construction, as well as Sabina Szymczak for excellent research assistance. Anonymous referees and participants of the conference organised by the Department of International Trade of Cracow University of Economics (Cracow, 20 November 2017) provided useful comments which allowed to increase the value of this article. The hospitality of University of California, Berkeley and the support of Polish-U.S. Fulbright Commission is gratefully acknowledged.

\section{Copyright and License}

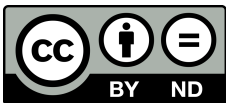

This article is published under the terms of the Creative Commons Attribution - NoDerivs (CC BY-ND 4.0) License http://creativecommons.org/licenses/by-nd/4.0/

Published by the Centre for Strategic and International Entrepreneurship - Krakow, Poland 
